\title{
METHOD OF ADMINISTRATIVE-TERRITORIAL ZONING OF THE DESIGN PARAMETERS OF AIR TEMPERATURE
}

\section{Victor Pashynskyi}

Scientific paper / Znanstveni rad

Department of building, road machines and construction, Central Ukrainian National Technical University, Kropyvnytskyi, Sc. D., Professor

Corresponding author: pvakntu@gmail.com

\section{Mykola Pashynskyi}

Department of building, road machines and construction, Central Ukrainian National Technical University, Kropyvnytskyi, PhD

Natalya Pushkar

Department of reinforced concrete constructions and transport constructions, Odessa State Academy of Civil Engineering and Architecture, Odessa, Associate Professor

\section{Ivan Skrynnik}

Department of building, road machines and construction, Central Ukrainian National Technical University, Kropyvnytskyi, Associate Professor

\begin{abstract}
This study proposes a method of administrative-territorial zoning of the major design parameters of the air temperature. For each administrative region, the design values of the mean temperature of the year, the temperatures in the coldest and the warmest month, and the temperature of the coldest and the warmest day are set. These parameters can be applied during the building and in the structural design of the entire region. The study was conducted in Ukraine, however, is applicable to all countries.
\end{abstract}

Keywords: air temperature; meteorological data; territorial variability

\section{METODOLOGIJA ADMINISTRATIVNO-TERITORIJALNOG ZONIRANJA PARAMETRA UTJECAJA TEMPERATURE ZRAKA NA ZGRADE}

Sažetak: U ovome se radu predlaže metoda administrativno-teritorijalnog zoniranja glavnih projektnih parametara temperature zraka. Za svaku administrativnu regiju postavljaju se projektne vrijednosti srednje temperature u godini, temperatura najhladnijeg i najtoplijeg mjeseca, temperatura najhladnijeg i najtoplijeg dana. Ovi parametri trebaju se koristif tjekom izgradnje i konstrukcijskog oblikovanja čitave regije. Metoda se temelji na primjeru područja Ukrajine, ali je primjenjiva na sve države.

Ključne riječi: temperatura zraka; meteorološki podaci; teritorijalna varijabilnost 


\section{INTRODUCTION}

The atmospheric temperature has a significant impact on the enclosing and the load-bearing structures in addition to the properties of the building materials used. Many studies have been conducted to analyze these effects $[1-6]$.

The parameters of the air temperature that determine the energy efficiency of the buildings in the southern regions of Chile were analyzed and updated [4]. In addition, the use of regression equations to predict the minimum and the maximum surface temperature of the pavement depending on the air temperature have been justified [6]. Influence of the air temperature on the enclosing structures in Ukraine, has been studied and summarized [1]. Based on the probabilistic representation, the design values of the air temperature required for the thermal design of the enclosing structures have been calculated and the territorial zoning of these design values has been performed.

The thermal actions on the load-bearing structures have been considered. Using the probabilistic methods, the design values of the annual temperature changes were determined and the impact of these differences on the steel and the reinforced concrete frames of single-story buildings were analyzed [2]. The theoretical model to predict the temperature of the bridges was proposed, taking into account the air temperature and the solar radiation [3]. The effects of the air temperature on the deformation and the displacement of steel bridges were experimentally demonstrated and the necessity to consider the temperature changes during the stress-strain analysis was emphasized [5].

Significant changes in the time and the territory require a probabilistic representation of the temperature in the form of random variables, processes, and fields. Probabilistic models for describing the atmospheric temperature were developed in many studies [1, 2, 7-9]. According to the data from the Croatian meteorological stations, a comparative analysis of the formulas for determining the mean daily air temperatures was performed [7]. Analysis of the long-term changes in the mean annual values and the standards of the air temperature were performed in Croatia $[8,9]$. Increase in the mean temperatures and their variability over the last decades have been identified. The possibility of using a probabilistic model of a quasi-stationary random process with an annual period of nonstationarity has been confirmed [1,2]. In addition, these works provide the statistical characteristics of the air temperature to the weather stations in Ukraine.

The traditional method of displaying the territorial variability in the climatic loads and the impacts is the allocation of the climatic regions, in particular, the creation of territorial zoning maps [1,2, 10-11]. The zoning maps of the statistical characteristics and the design values of the minimum (winter) air temperature for thermal insulation of the buildings in Ukraine have been developed [1]. The territorial zoning maps of the design values of the air temperature as the thermal actions on the load-bearing structures have been provided [2]. A new method of territorial zoning based on a set of climatic indicators that affect the energy efficiency of buildings has been proposed [11]. An analysis of the climatic parameters and the existing methods of territorial zoning for assessing the energy efficiency of buildings has been provided [10]. It proved that a lack of consensus on the climate zoning methodology indicates the need for further research. Ukrainian standard, instead of the traditional maps, contains the required design parameters of the air temperature for the network of 57 meteorological stations [12].

Studies propose a method of administrative-territorial zoning, based on establishing a single design value of the climatic load or the impact within the entire administrative region, which will provide the necessary reliability level for the structural design in the region $[13,14]$. The results of zoning are presented in the form of a table, each line of which contains the required design parameters of the load or the impact on a certain administrative unit, in Ukraine. The advantages of such a method of territorial zoning are the compact presentation of the results, and the simplicity and the accuracy during the determination of the design values of loads and impacts on the building site.

An analysis of the accuracy of the administrative-territorial zoning was performed using the snow weight load, the maximum wind pressure, the weight of ice, and the wind pressure under ice conditions [14]. It was established that the probable errors in the administrative-territorial zoning did not exceed the errors in the maps provided in the load standards [15]. However, the administrative-territorial zoning of the air temperature parameters was not performed.

This study aims to validate the method of the administrative-territorial zoning of the main statistical characteristics and the design values of the air temperature using Ukraine as an example. 


\section{OUTPUT DATA}

As the source information, the generalized results of the air temperature observations performed according to the standard method were used. The air temperature was measured in the psychrometric booths at an altitude of $2 \mathrm{~m}$ above the ground level. The data from the 371 weather stations located in the plain terrain, were analyzed. As the data from the weather stations located in the different areas of large cities are similar, they were combined into one. The mean monthly air temperatures for the whole city were calculated as the weighted mean values, according to the data from the available weather stations, considering the number of years of observations at each weather station.

In addition, the data from the weather stations located in the mountainous regions of Crimea and Carpathians, at heights above $500 \mathrm{~m}$ of mean sea level, were not considered. This approach corresponded to the principles of the Eurocodes, where special adjustments are made for loads depending on the altitude. Table C.1 of EN 1991-13: 2003 provides such coefficients for snow load in different regions of Europe [16]. Such adjustments are introduced for altitudes above $500 \mathrm{~m}$ above the sea level in the load standards of Ukraine [15]. Territorial zoning maps of the characteristic values of the climatic loads were developed according to the data from the weather stations located at altitudes of up to $500 \mathrm{~m}$ above the sea level. To unify the load standards in Ukraine [15], the territorial zoning was performed for the plain areas of Ukraine. The decrease in the air temperature in the mountainous areas with an increase in the altitude should be considered according to the known dependence in climatology (the temperature decreases by $6{ }^{\circ} \mathrm{C}$ with an increase of $1000 \mathrm{~m}$ in the altitude).

Figure 1 shows the histograms for the distribution of the weather stations as per the altitude above the sea level and the number of years of observation.
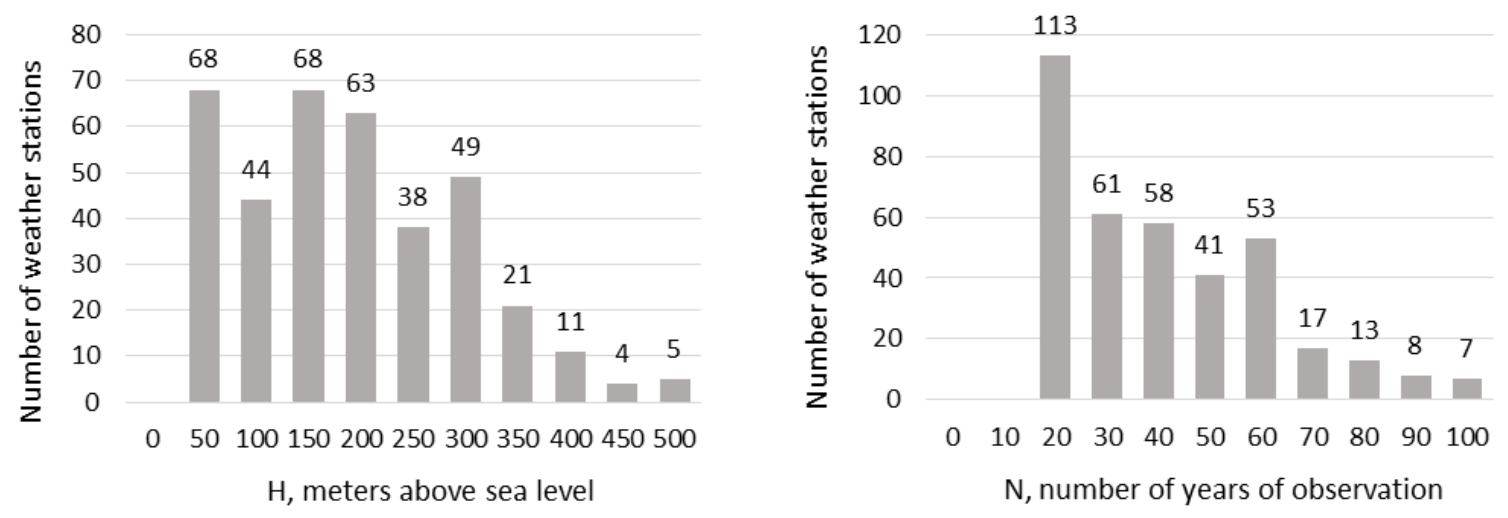

\section{Figure 1 Histograms showing the distribution of the number of weather stations as per the altitude above the sea level, $\mathrm{H}$, and the number of years of observation, $\mathrm{N}$}

The figure shows that a majority of weather stations are at an altitude of up to $300 \mathrm{~m}$ above the sea level. The duration of monitoring the air temperature varied from 11 to 100 years. For a majority of weather stations, the data were available from 11 to 60 years. Closely located observation points compensated the presence of $30 \%$ of the weather stations with short rows of observations, up to 20 years.

The distribution used to study the weather stations in the plain areas as per the regions of Ukraine, is shown in Table 1. The least number of weather stations (three) are located in the Chernivtsi region, and the most (46) in the Crimea region. This is because of the considerable variability of climatic conditions in the plain, the mountainous territory of Crimea, and its southern shore. Owing to the subtropical climate in the Southern coast of Crimea, the weather stations had to be isolated to a separate zone, located south of the Crimean Mountains.

A dense network of weather stations and the available volume of meteorological observations provided an opportunity for a detailed analysis of the territorial variability of the parameters of the air temperature.

The main source for territorial zoning is the mean monthly air temperature values and the mean annual air temperature values, from the monograph in [1]. The temperature standards for January and July for all the weather stations were calculated using the formulas from [1] as 


$$
\begin{aligned}
& S_{1}=5.31-0.15 \cdot M_{1}+0.0075 \cdot M_{1}^{2}-0.00024 \cdot M_{1}^{3}, \\
& S_{7}=5.31-0.15 \cdot M_{7}+0.0075 \cdot M_{7}^{2}-0.00024 \cdot M_{7}^{3},
\end{aligned}
$$

where $M_{1}$ and $M_{7}$ are the mean air temperatures for January and July, respectively.

The design values of the minimum and the maximum air temperatures in the shade for each weather station were calculated using the formulas from [1] as

$$
\begin{aligned}
& T_{\text {min }}=M_{1}-S_{1} \sqrt{2 \ln (4,8 \omega n),} \\
& T_{\text {max }}=M_{7}-S_{7} \sqrt{2 \ln (4,8 \omega n)},
\end{aligned}
$$

where, $M_{1}, S_{1}, M_{7}$, and $S_{7}$ are the mean values and the standard deviations of the random processes of temperature in January and July, respectively.

In Eqs. (3) and (4), $\omega=0.61 /$ day, the mean frequency of the random process of the air temperature [1]; $n=50$ years, the return period of a design value of the temperature.

The return period, $n=50$ years, corresponds to the probability of being in excess of 0.02 , adopted in the standard [12].

Owing to the observations at the 371 weather stations, the database had the following parameters in ${ }^{\circ} \mathrm{C}$ :

- mean January temperature, $M_{1}$;

- mean July temperature, $M_{7}$;

- mean temperature of the year, Myear,

- minimum air temperature in the shade, $T_{\text {min; }}$

- maximum air temperature in the shade, $T_{\max }$.

\section{METHODS AND RESULTS OF ZONING OF THE AIR TEMPERATURE PARAMETERS}

Representing the design parameters of the air temperature in the form of a table, as in [12], or in the form of a map, as in [1, 2], have a number of shortcomings. The major ones are the subjectivity of choosing the nearest meteorological station from the list [12], uncertainty near the territorial regions using the schematic maps [1, 2], and the need to develop and use a separate map for each of the design parameters.

An alternative is the administrative-territorial zoning, which uses the official administrative division of the state. In this method, for each administrative region the values of the design parameters are determined with the required level of reliability. Regional design values are represented as a table, each row of which corresponds to a certain area. A small number of administrative regions of Ukraine provide a compact presentation of the results. The exact placement of a construction site in a certain administrative region guarantees the convenience, the simplicity, the speed, and the accuracy in the determination of the design parameters.

The administrative-territorial zoning of the design parameters of the air temperature was performed according to the methods specified in [13, 14]. All the 371 plain weather stations were divided into 25 groups as per the number of regions in Ukraine. The southern coast of Crimea with its subtropical climate, that is different from the climate in the plain region in Ukraine, was allocated to a separate zone. The number of weather stations in each region is shown in Table 1. Owing to the statistical treatment, the mean values and the standard deviations for each of the five design parameters listed below for all the 26 regions of Ukraine were determined. The obtained statistical characteristics reflect the variability in the design parameters of the air temperature within the territory of each region and the southern coast of Crimea. Regional design values were based on the normal distribution of the design parameters within the region. Therefore,

- the mean air temperature for January and the minimum air temperature in the shade, served as the minimum value within the region with a confidence level of 0.95 ;

- the mean air temperature for July and the maximum shade air temperature served as the maximum value within the region with a confidence level of 0.95 ;

- the mean temperature of the year served as a mean value within the region.

A confidence level of 0.95 indicates that the regional design values of the air temperature parameters are reliable for approximately $95 \%$ of the territory. 
Obtained regional characteristics of the air temperature are given in Table 1. The table shows the mean air temperature for January, $M_{1}$; the mean air temperature for July, $M_{7}$; the mean temperature of the year, $M_{y e a r}$; the minimum shade air temperature, $T_{\min }$; and the maximum shade air temperature, $T_{\max }$. The mean monthly values and the mean temperature of the year were rounded off to $0.1^{\circ} \mathrm{C}$, and the design values were up to $1^{\circ} \mathrm{C}$, as per the standard in [12].

Table 1 Design parameters of the air temperature for the Ukraine

\begin{tabular}{|c|c|c|c|c|c|c|}
\hline \multirow{2}{*}{ Regions of Ukraine } & \multirow{2}{*}{$\begin{array}{l}\text { Number of } \\
\text { weather } \\
\text { stations }\end{array}$} & \multicolumn{5}{|c|}{ Design parameters $\left[{ }^{\circ} \mathrm{C}\right]$} \\
\hline & & $M_{1}$ & $M_{7}$ & $M_{\text {year }}$ & $T_{\min }$ & $\mathrm{T}_{\max }$ \\
\hline Vinnytsia & 15 & -6.6 & 19.9 & 7.2 & -28 & 31 \\
\hline Volyn & 6 & -3.9 & 18.4 & 7.4 & -23 & 30 \\
\hline Donetsk & 17 & -7.4 & 22.6 & 7.8 & -29 & 32 \\
\hline Zhytomyr & 11 & -6.5 & 19.5 & 6.8 & -27 & 30 \\
\hline Zakarpattia & 14 & -5.0 & 21.0 & 8.2 & -25 & 31 \\
\hline Zaporizhia & 13 & -5.4 & 24.1 & 9.1 & -25 & 33 \\
\hline Ivano-Frankivsk & 18 & -6.1 & 19.7 & 7.0 & -27 & 31 \\
\hline Kiev & 16 & -7.0 & 19.8 & 7.0 & -28 & 31 \\
\hline Kirovohrad & 13 & -6.4 & 21.6 & 7.9 & -27 & 32 \\
\hline Plain district of Crimea & 29 & -2.3 & 24.0 & 10.4 & -20 & 33 \\
\hline Southern coast of Crimea & 17 & 0.7 & 25.1 & 12.2 & -16 & 33 \\
\hline Luhansk & 10 & -8.2 & 22.2 & 7.3 & -31 & 32 \\
\hline Lviv & 28 & -4.8 & 18.7 & 7.4 & -24 & 30 \\
\hline Mykolaiv & 9 & -5.0 & 23.0 & 9.4 & -25 & 32 \\
\hline Odessa & 21 & -4.9 & 23.1 & 9.7 & -25 & 32 \\
\hline Poltava & 13 & -7.1 & 21.6 & 7.3 & -29 & 32 \\
\hline Rivne & 4 & -4.8 & 18.7 & 7.3 & -24 & 30 \\
\hline Dnipropetrovsk & 13 & -6.3 & 22.3 & 8.3 & -27 & 32 \\
\hline Sumy & 14 & -8.3 & 20.4 & 6.3 & -31 & 31 \\
\hline Ternopil & 7 & -5.9 & 19.1 & 7.2 & -26 & 30 \\
\hline Kharkiv & 17 & -8.0 & 21.4 & 6.9 & -30 & 31 \\
\hline Kherson & 18 & -3.7 & 23.6 & 9.9 & -23 & 32 \\
\hline Khmelnytskyi & 9 & -6.0 & 19.1 & 7.1 & -27 & 30 \\
\hline Cherkasy & 20 & -6.6 & 20.9 & 7.4 & -28 & 31 \\
\hline Chernivtsi & 3 & -5.7 & 19.4 & 8.2 & -26 & 30 \\
\hline Chernihiv & 16 & -7.8 & 19.9 & 6.3 & -30 & 31 \\
\hline Minimum values of parameters & & -8.3 & 18.4 & 6.3 & -31 & 30 \\
\hline Maximum values of parameters & & 0.7 & 25.1 & 12.2 & -16 & 33 \\
\hline Swing of temperature parameters & & 9.0 & 6.7 & 5.9 & 15 & 3 \\
\hline
\end{tabular}

The last lines of the table contain the limits of the change in the investigated characteristics in Ukraine. Average annual regional air temperature values in Ukraine changed up to $5.9^{\circ} \mathrm{C}$. The maximum air temperature in the shade was approximately stable, varying within $3^{\circ} \mathrm{C}$. The largest territorial variability with a magnitude of $9^{\circ} \mathrm{C}$ and $15^{\circ} \mathrm{C}$ is typical for the mean January temperatures and the design temperatures of the coldest day. If the Southern coast of Crimea with its subtropical climate was excluded from the analysis, these changes were reduced to $6^{\circ} \mathrm{C}$ and $11^{\circ} \mathrm{C}$. This confirms the expediency of allocating the Southern coast of Crimea in a separate temperature zone with substantially higher winter air temperatures. 


\section{ESTIMATION OF ACCURACY AND RELIABILITY OF THE AIR TEMPERATURE ZONING PARAMETERS}

Table 1 is the result of zoning and allows the determination of the required design parameters of the air temperature for a random geographical point in the administrative regions of Ukraine.

The accuracy of the performed administrative zoning was estimated by statistical treatment of the differences between the design parameters of the region and the actual parameters of the air temperature on each weather station, calculated based on the meteorological data. For the analysis, the samples of deviations in the five design parameters for the 371 weather stations were generated. The statistical characteristics of these deviations are given in Table 2.

Table 2 Statistical characteristics of the deviations of the design parameters of the air temperature from the regional design values

\begin{tabular}{cccccc}
\hline Statistical characteristics of the & \multicolumn{3}{c}{ Deviation of the design parameters $\left[^{\circ} \mathbf{C}\right]^{\prime}$} \\
deviations & $\mathbf{M}_{\mathbf{1}}$ & $\mathbf{M}_{\mathbf{7}}$ & $\mathbf{M}_{\text {year }}$ & $\mathbf{T}_{\min }$ & $\mathbf{T}_{\max }$ \\
\hline Mean value & -1.47 & 1.15 & 0.00 & -2.45 & 0.62 \\
Standard deviation & 1.23 & 0.92 & 0.63 & 1.85 & 0.50 \\
90\% confidence interval & -3.5 & -0.4 & -1.0 & -5.5 & -0.2 \\
Confidence level & 0.5 & 2.7 & 1.0 & 0.6 & 1.4 \\
\hline
\end{tabular}

The data in Table 2 indicates, in general, the sufficient accuracy of the administrative-territorial zoning of the air temperature parameters. Mean values of the temperature deviations were negative in January and positive in July, which created the necessary reserves of reliability. For $90 \%$ weather stations, the deviation did not exceed the limits of $-3.5^{\circ} \mathrm{C}-+5.5^{\circ} \mathrm{C}$. The confidence level of territorial zoning was equal to $0.96-0.97$, which means for 96-97\% weather stations, the administrative-territorial zoning was performed with sufficient reliability level. The analysis of the deviations in the selected regions of Ukraine showed that the parameters of air temperature were most variable in the Odessa region, which had a considerable coastal area, as well as in the regions of Ukraine with mountainous terrains.

To illustrate the nature of the territorial variability of the air temperature parameters, the schematic maps of Ukraine are shown in Figure 2. The regional design values of the temperature of the coldest day, $X_{\min ,}$ and the warmest day, $X_{\max }$ have been taken from Table 1.
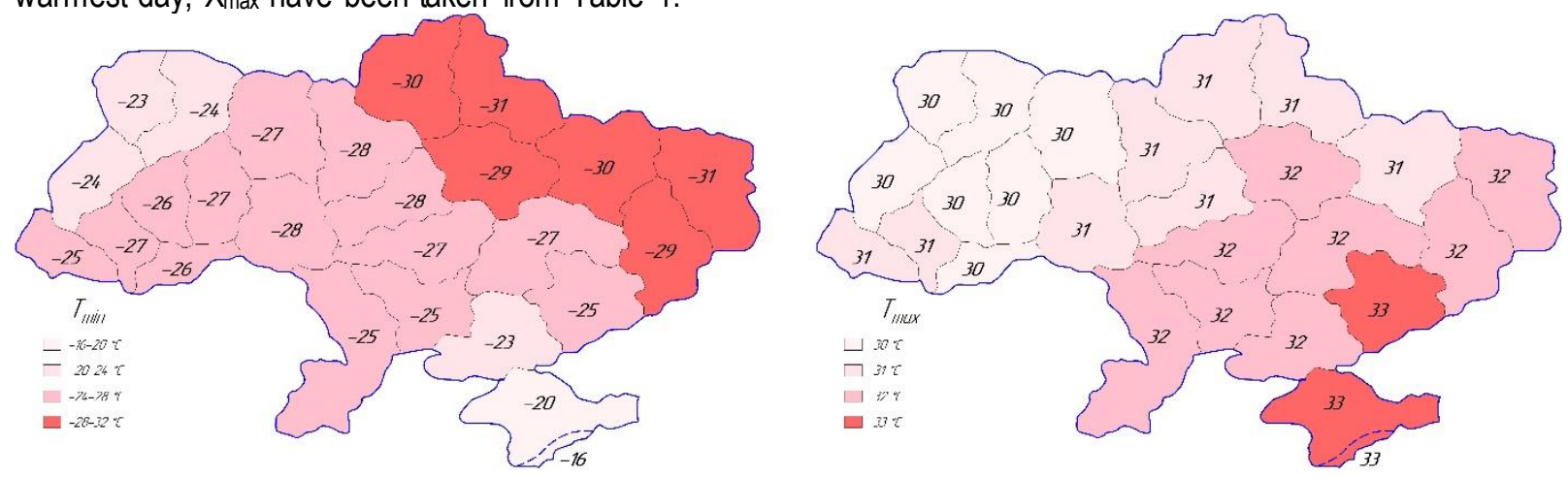

Figure 2 Design values of the air temperature for regions of Ukraine

Figure 2 shows that the design temperature values for the minimum air temperature in the shade systematically increase from the north to the south of Ukraine with an exception in the northwest. The design temperature values for the maximum air temperature in the shade increase from the northwest to the southeast of Ukraine. The general nature of the territorial variability of the air temperature was approximately similar to the zoning maps from [1, 2]. This confirmed the adequacy of the performed zoning and the possibility of using the design values from Table 1 during the building and in the structural design of the entire region. 


\section{SUMMARY}

1. The administrative-territorial zoning of the design parameters of the air temperature was performed according to the data from the 371 weather stations in the plain regions of Ukraine. Depending on the size of the region and the variability of climatic conditions, there were approximately 3 to 29 weather stations located in each region of Ukraine. The duration of the series of observations of the air temperature varied from 11 to 100 years, however, for many observations it was from 11 to 60 years.

2. For each of the 25 administrative regions of Ukraine and separately for the Southern coast of Crimea, the region design values of the five air temperature parameters with the necessary reliability level were set. The parameters were the mean temperature in January and July, the minimum and the maximum air temperature in the shade, and the mean temperature of the year. The results of zoning were summarized in a table, the data of which is recommended to be used during the building and in the structural design of the entire region.

3. The statistical analysis of the deviations of the established regional design values from the actual values of the air temperature parameters at all the weather stations showed that the administrative-territorial zoning was performed with sufficient reliability level, and its errors did not exceed the errors in the tabular or the cartographic methods of zoning.

4. The performed administrative-territorial zoning provides the convenience, the speed, and the reliability while determining the design parameters of the air temperature owing to the exact location of a construction site to a certain administrative region of Ukraine. This adds to the reason for its recommendation to be applied to the building and in the structural design of the region.

\section{References}

[1] Pashynskyi, V.A., Pushkar, N.V., Kariuk, A.M. 2012: Temperaturni vplyvy na ohorodzhuvalni konstruktsii budivel, Odeska derzhavna akademiia budivnytstva ta arkhitektury, Odessa - 180 p. (in Ukrainian)

[2] Dorofieiev, V.S., Pushkar, N.V., Pashynskyi, V.V. 2014: Napruzheno-deformovanyi stan stalevykh karkasiv pry temperaturnykh vplyvakh, Odeska derzhavna akademiia budivnytstva ta arkhitektury, Odessa -160 p. (in Ukrainian)

[3] Hirst, M.J.S., Dilger, W.H. 1989: The Prediction of Bridge Temperatures, IABSE Periodica, 3, pp. 109-120. http://doi.org/10.5169/seals-41973

[4] Verichev K., Carpio, M. 2018: Climatic zoning for building construction in a temperate climate of Chile, Sustainable Cities and Society, 40, pp. 352-364. https://doi.org/10.1016/j.scs.2018.04.020

[5] Kovačič, B., Gubeljak, N., Lubej, S. 2019: Experimental Investigation of the Effect of Temperature on the Structures in the Measurement of Displacements. Tehnički vjesnik, 26 (4), pp. 1010-1016. https://doi.org/10.17559/TV-20180525142550

[6] Matić, B., Tepić, J., Sremac, S., Radonjanin, V., Matić, D., Jovanović, P. 2012: Development and evaluation of the model for the surface pavement temperature prediction. Metalurgija, 51 (3), pp. 329-332.

[7] Bonacci, O., Roje-Bonacci, T., Željković, I. 2017: A comparison of the mean value of air temperature (on different time scales) calculated by two different methods. Hrvatske vode, 25 (101), pp. 169-176.

[8] Bonacci, O. 2010: Analysis of mean annual air temperature series in Croatia. Građevinar, 62 (09.), pp. 781791.

[9] Jurun, E., Hodžić, M., Greguš, M. 2011: The significance of air temperature oscillations in the last decade in Split - Croatia. Croatian Operational Research Review, 2 (1), pp. 244-254.

[10] Walsh, A., Costola, D., Labaki, L.C. 2017: Review of methods for climatic zoning for building energy efficiency programs, Building and Environment, 112 pp. 337-350. https://doi.org/10.1016/j.buildenv.2016.11.046

[11] Xiong, J., Yao, R., Grimmond, S., Zhang, Q., Li. B. 2019: A hierarchical climatic zoning method for energy efficient building design applied in the region with diverse climate characteristics, Energy and Buildings, 186 (2019), pp. 355-367. https://doi.org/10.1016/j.enbuild.2019.01.005

[12] DSTU-N B V.1.1-27:2010 Zakhyst vid nebezpechnykh heolohichnykh protsesiv, shkidlyvykh ekspluatatsiinykh vplyviv, vid pozhezhi. Budivelna klimatolohiia, Kiev, 2010. (in Ukrainian)

[13] Filimonykhyn, G.B., Pashynskyi, M.V. 2018: Metod admynystratyvno-terrytoryalnoho raionyrovanyia klymatycheskykh nahruzok na stroytelnye konstruktsyi, Vestnyk BRU, pp. 121-128. (in Ukrainian) 
[14] Pashynskyi V.A, Filimonikhin G.B., Pashynskyi M.V. 2018: Raionuvannia kharakterystychnykh znachen klimatychnykh navantazhen na terytorii Ukrainy, Kiev, Vyd-vo «Stal» pp. 88-100. (in Ukrainian)

[15] DBN V.1.2-2:2006. Systema zabezpechennia nadiinosti ta bezpeky budivelnykh obiektiv. Navantazhennia i vplyvy. Normy proektuvannia. Kyiv. MINBUD UKRAINY, 2006. (in Ukrainian)

[16] EN 1991-1-3 (2003): Eurocode 1: Actions on structures - Part 1-3: General actions - Snow loads.

Please cite this article as:

Pashynskyi, V., Pashynskyi, M., Pushkar, N., Skrynnik, I.: Method of administrative-territorial zoning of the design parameters of air temperature, Electronic Journal of the Faculty of Civil Engineering Osijek-e-GFOS, 2019, 19, pp. 50-57, htps://doi.org/10.13167/2019.19.5 